UDC 378.1

DOI: $10.24044 / \mathrm{sph} .2017 .3 .10$

\title{
DEVELOPMENT OF TRAINING PROGRAMS FOR PEDAGOGICAL PHYSICS STUDENTS BASED ON LEARNER CAPABILITY AT VINH UNIVERSITY - VIETNAM
}

N. Nguyen Thi

\author{
Ph.D., assistant professor \\ Vinh University \\ Vinh City, Vietnam
}

\begin{abstract}
Developing the training programs to meet the social demands is a critical tendency all over the world, especially in Vietnam, where, in fact, many graduates cannot find their jobs or have to be re-trained to start a work. Developing the training programs to meet the social demands is defined as the designing and practicing program contents, teaching and studying activities and consistent evaluation to reach the designed output capability frame for social requirement. Developing the training programs to meet the social demands mainly depends on some characteristics of education and training trend based on output standards. The development of training program, in general and of pedagogy training program, in particular is driven by the development of necessary capacities for social demands that learners should have for a good job or for personality development after their graduation. This article is focused on the development of training program for bachelor of physical pedagogy in direction to access the learner's capability in Vinh University - Vietnam.
\end{abstract}

Keywords: physics; training program; capability; Vinh University; study content.

1. Training program for bachelor of physics pedagogy in direction to develop the learner's capability

Capability is defined as the organizational combination of skill, knowledge and attitude, emotions, and motivational values to effectively meet the complex requirements of different activities in a given context.

Capability development pays attention to logics and structure of qualities and abilities that make up the personality of the students. Therefore, intergrated education and training following internal subjects, inter-subjects and inter-areas is denoted to be the mainstreaming method in such processes as design, target, program output stand- ards, choosing subject content, educational activities, teaching methodology and testing and evaluation.

When developing a curriculum based on capability approach, there are a number of orientations:

- The approach to the formation of individual and human capacities is to form, strengthen and develop the capacities and needs that constitute the nature of people with the potentials to live and work; to search, choose, access and proceed information, thereby learning the knowledge and skills through critical thinking and criticism. These are general capacities and specialized capacities. 
The material objects for direct and regular manipulation of teachers and students are subjects reflected in the content of the curriculum. The biggest obstacle of the programmers, especially the teachers while teaching is to disclose the method - how the scientist has found and manipulated that knowledge. Due to this obstacle, there are so many different opinions, sometimes there is hot debate between one party who believes that the more and the deeper the knowledge, information are, the more qualified the students are, for example, in mathematics the program must be reduced by accepting theorems without proving it, with one party who believes that the focus point is to teach students the way to do, to think, to formulate metacognition. Thereby, some pedagogics proposed to teach the history of scientific ideas as the description of subject content. Both of these two opions are right, but only in one side, and it will be a serious mistake if being too radical. Training program development based on content approach will be easily prone to extreme state of knowledge provision in construction, description of goals, content and methods of education, testing, assessment and quality management. In order to avoid such a situation, it is necessary to develop the capability-based program with a structural design including qualitative, ability standards and criteria that are clearly described at different levels of the output and the process of forming that output. This assertion is made with solid basis that: accumulation of avail- able, separate and academic knowledge does not certainty establishes the capability for action in learners, however, with training and capability development by organization of activities to apply grasped knowledge in the whole process, the output of the process will have both knowledge and the way to search for that knowledge. This renovative education methodology can only be practical in real school when all factors of this program are consistently for the capability development target. Difficulty of this activity-organizationapproach method is that it is difficult for the illustration of subject content in curriculum and textbooks to show the "HOW" factor, to make all knowledge information become "open" resulting in teacher and students being lazy. Another difficulty of this approach is that teachers are not fully equipped with theoretical basis and especially the intergrated teaching organization skills. The nature of this intergration is to apply knowledge and skills from different sources to solve a matter helpful for our awareness. Therefore, it is necessary to combine different knowledge fields, intergrate the general capability and specialized capability and intergrate ability and content. Each intergration fomular has its own value and is organized by specific, diverse activities. Thanks to that teachers are able to realize them creatively. Comparing content-approach program and capability-approach program, there are some following differences: 


\begin{tabular}{|c|c|c|}
\hline Features & Content-approach program & S \\
\hline \multicolumn{3}{|c|}{ 1. Program module } \\
\hline Key point & - Approach knowledge & - Create knowledge (with guideline) \\
\hline Activity type & From teacher to students & $\begin{array}{l}\text { - Cooperation between teacher and stu- } \\
\text { dents }\end{array}$ \\
\hline Study type & $\begin{array}{l}\text { - Mainly receive knowledge, cog- } \\
\text { nitive skills; } \\
\text { - Emphasize cognitive skills, logi- } \\
\text { cal thinking } \\
\text { - Each information and skills are } \\
\text { introduced discontinuously and } \\
\text { less repeated in each subject }\end{array}$ & $\begin{array}{l}\text { - Apply knowledge, skills, attitudes in- } \\
\text { tegrated in the context of employment } \\
\text { to develop capability } \\
\text { - Emphasize cognitive skills, critical } \\
\text { thinking, and communication skills } \\
\text { - Each capability is continuously devel- } \\
\text { oped in many areas / subjects, time to } \\
\text { time }\end{array}$ \\
\hline Responsi & ble for & $\begin{array}{l}\text { - Provide resources as well as be re- } \\
\text { sponsible for the output result }\end{array}$ \\
\hline \multicolumn{3}{|c|}{ 2. Program factors } \\
\hline $\begin{array}{l}\text { Target/ Output } \\
\text { results }\end{array}$ & $\begin{array}{l}\text { - Require specific knowledge, } \\
\text { skills, attitudes } \\
\text { - Be determined on the basis of } \\
\text { subject content requirements } \\
\text { - Expectations for learners }\end{array}$ & $\begin{array}{l}\text { - Capability development level (the } \\
\text { combination knowledge, skills, atti- } \\
\text { tudes, feelings, motivation and emotion) } \\
\text { - Be developed based on the output de- } \\
\text { mands of social works } \\
\text { - Expectations for both learners and } \\
\text { teachers }\end{array}$ \\
\hline Study & $\begin{array}{l}- \text { Select the nec } \\
\text { from the subject } \\
\text { - Organize cc } \\
\text { based on subject }\end{array}$ & $\begin{array}{l}\text { - Select the skills needed for students in } \\
\text { real life } \\
\text { - Organize content primarily in a manner } \\
\text { that capability is well developed }\end{array}$ \\
\hline $\begin{array}{l}\text { Teaching and } \\
\text { study method- } \\
\text { ology }\end{array}$ & $\begin{array}{l}\text { - Be derived from experience in } \\
\text { the study of subject science } \\
\text { - Pay attention to how to organi- } \\
\text { zation of learning the content of } \\
\text { the program } \\
\text { - Adapt to the experience of the } \\
\text { class as they study each subject }\end{array}$ & $\begin{array}{l}\text { - Be derived from the experience asso- } \\
\text { ciated with real life } \\
\text { - Pay attention to the potential devel- } \\
\text { opment organization already available } \\
\text { in each person } \\
\text { - Adapt to the experience of each per- } \\
\text { son in his learning and life }\end{array}$ \\
\hline $\begin{array}{l}\text { Learner's as- } \\
\text { sessment }\end{array}$ & $\begin{array}{l}\text { - Emphasize the knowledge and } \\
\text { skills that have been specified } \\
\text { - Focus on summative assessment } \\
\text { - Focus on measuring objectives } \\
\text { of single subject } \\
\text { - Mainly prepared and practiced } \\
\text { by teachers } \\
\text { - Normally collect information in } \\
\text { some fixed times }\end{array}$ & $\begin{array}{l}\text { - Emphasize the actual outputs of each } \\
\text { student (real assessment) } \\
\text { - Focus on process evaluation (progress } \\
\text { monitoring) and summative reviews } \\
\text { - Focus on measuring different capaci- } \\
\text { ties in real activities of students. } \\
\text { - By teachers and students } \\
\text { - Collect information in a long period } \\
\text { (profile, project, etc.) }\end{array}$ \\
\hline
\end{tabular}


2. Developing training program for bachelor of physical pedagogy based on capability approach at Vinh University, VietNam

2.1. Practical basis for the development of higher education programs in Universities

According to Mrs Nguyen Thi Binh (Former Minister of Education and Training), experience of the world approves that the good quality general education is the solid basis for a advanced and modern national education. As we all know, general education from primary to high school plays a vital role in the fomulation of first features of a person, in terms of morality, feelings, understanding (knowledge), living skills, etc. At this age, children are like the blank paper on which adults (parents, teachers) could help them to draw the very first strokes in their lives, from which to develop qualities already available in each body. These strokes are the starting point for their following process. Good first strokes will probaly result in convenient and good next processes. In terms of development, learning is important, but emotional and moral stimulation and nurturing are even more neccessary and important. They have to be loved, educated to grow up, to be filial to their parents, to love their friends and neighbors, to love their homeland, their Land, to be Vietnamese with history and culture of Vietnam. They must be guided to live honestly, civilizedly and friendly with other peoples, but they must be firstly prepared to serve the country of
Vietnam. In other words, if the function of education is teaching people, teaching words, vocational training, it must start from here and need to do the best these first step.

In fact, education management in Vietnam Higher education has made its "breakthrough) in program management and development from "reducing the amount of basic college tuition". Eight universities in Vietnam have piloted the Dutch-based careerorientation higher education program (POHE). Accordingly, they all cut the teaching time of basic science subjects compared to the old program by 12 $60 \%$. This information was announced in the four-year review of the Dutch-based Career-Orientation Program (POHE) organized by the Ministry of Education and Training on December 16th, 2015. According to the report on student assessment of this project, the rate of students who fail the tests of basic subjects is comperatively high. Most of them are the first-year student.

When participating in this pilot project, the time for basic subjects is all transferred to content subject for living skill and vocational skill trainings. Accordingly, based on the ability of the schools and the results of their self-surveys of labor demand in the local areas or nationwide,these schools develop a curriculum framework with new knowledge and skills related to the subject, namely intercommunicaton, communication, management, teamwork, etc.

It can be said that the orientation and direction to renovate general 
education in Vietnam have been clearly defined, with the approach of modern educational theory and in accordance with the real situation of the country. However, the raised problem has not been solved, the breakthrough from the pedagogical school (teacher training institutions) needs to be solved in term of the professional perspective: namely, Educational program; content; training mode; assessment and related issues.

The results of interviews with some managers in high schools and education and training departments in Vietnam share the common opinion that: The demand for new capability of general teacher is the real quality demand - require to retrain and refoster some teachers; Training programs at pedagogic colleges need to focus on the training of teacher's education capability, new teaching techniques, social skills and communication skills; The goal of standardized general teacher education (issued) is an urgent requirement for pedagogical colleges;

The demand for comprehensive innovation in teacher training is really imperative. And the logical scientific path should follow these steps by steps: Firstly, it is necessary to change all the teachers' perceptions of the curriculum and program development (at least from the level of the lecture); Secondly, the management and development of the program at the school level need the work of a team of educational professionals; Thirdly, based on international experience and educational practices, Vietnam's education needs a smart, natural and revolutionary choice; Fourthly, the pedagogical innovation and reform program, the requirement of practice, requires substantial financial investment from the Ministry of Education and Training, as well as the link in interests among pedagogical colleges in Vietnam.

International experiences in education development in general and the developement of teacher training programs and general education programs in particular are very rich and variable information sources which have fundamentally changed the awareness of the managing board and teachers. However, the transition in specific actions is still slow, with many obstacles requiring a more comprehensive strategy, determination and a clearer pathway, first of all from the management agencies and institutional systems. The results of research on theoretical and practical education of different countries help us to recognize the fact that education reformation must come from the national interest, from the quality of human personality, from the educational product, not the minor and detailed changes. In the mordernization of the High or Higher education programs of other countries, investment of financial support is not the sole and primary factor but the most important ones is the wayto change the perception of the education sector and the whole society, which is the cultural foundation rather than a separate way of education. This is the experience of many countries that have 
succeeded in developing educational programs.

The development of the program in general, the teacher training program in particular in different countries is a very rich reference resource. However, to apply it to Vietnam's sittuation we also need time to analyze and give a specific route.

Singapore's experience: In the speech on the occasion of the 2004 National Day, the Singapore Prime Minister Ly Hien Long said, "We have to teach less so that students can learn more". With this "Teaching less, Learning more" strategy, Singapore education focused on improving the quality of student's learning by creating more "space" in the curriculum so that teachers can make their own teaching plans, and create their own educational and professional training environment with students; students would be more active in learning, exploring knowledge through experiments, real-time experiences, learning living skills and building their own characters with effective and creative training strategies; students also had more opportunities to study and practice thoroughly to develop their thinking, personality and qualities to succeed in the future. The "Project Work" program, which allows students to learn how to work in teams and apply knowledge in practice, etc. helped students develop skills in the following four areas:

- Application of knowledge: Students can learn basic research skills, apply and transfer knowledge among different subjects, and create connections between them.

- Communication: Students learn how to communicate ideas in a clear and effective way.

- Collaboration: Students develop social skills through teamwork exercises to achieve common goals.

- Independent learning: Students are responsible for and manage their own learning, developing positive attitudes in learning and researching. To support the education reformation, the Singarporean Ministry of Education was committed to making changes in the curriculum structure and providing the necessary resources. The Ministry improved the flexibility and activity of the schools by cutting their curricula by 10-20\% to create "free time". Teachers were free to devote their time to making their own assignments, applying a variety of teaching methods and assessments to meet the needs of each student. The Ministry of Education cut two working hours per week for each teacher so they have more time for their teaching plan and professional experience sharing.

In order to successfully implement the "“Teaching less, Learning more" module, teachers and educational administrators must understand that active learning is a very distinct learning model. An active learner is the person who devotes all his attention and spirit for learning, the more positive the learner is, the better resuilt he gains. Applying this new module, the learner must be active in the learning process; Teachers only 
play a role of the person with guidance, encouragement and support.

Education Experience of Filand: Finnish education aims to achieve the same level of student achievement, this is one of the world's best education countries with students rated the best on by the PISA assessment (the abbreviation for The Program for International Student Assessment) which is an international student assessment program conducted by the Industrialized countries (OECD) and several other countries every three years.

According to the international expert Dr. Cary J. Trexler (University of California, Davis, United States): The federal government controls the education of each state with its own requirements. The entire education sector is governed by the state. In California, the Department of Education and the Board of Teacher Accreditation Councils are responsible for accreditation and licensing of teachers. Teacher salaries are decided by the school itself, the salary scale is calculated both by the level and the number of working years. Teacher training module in the United States is the four or five-year one, and teaching practices in the five-year curriculum are assessed as much more in terms of quantity and better in terms of quality. There are a parallel training module for general teachers and a parallel and continuous training module for teachers of vocational schools, vocational trainings, etc. The teacher's professional competence is assessed with a specific test or attendance in training program commissioned by the Teacher Accreditation Councils. In California, the state supports the training of teachers on the probation process in order to take the Teacher Licensure Examination. Teacher training in the United States is performed by states and schools.

In Australia, the national goal is defined that school education needs to maximize the talents and abilities of all students. Especifically, upon graduation, students must have the capability and skills to analyze and solve problems and be able to communicate ideas and information, prepare action plan, organize and collaborate with others; have a sense of selfconfidence, optimism of respect and commitment to learn as a basis for their potential role in the family and in the social community; be able to recognize and evaluate matters and be responsible for moral issues, respect for and follow the law, be able to think about their own world, find the causes of phenomena, make the right decisions, understand and be reasonable for their own life, and be responsible for any actions they take; be active and knowledgeable citizens with a high level of understanding and respect for the government system as well as for civic life in Australia; be equipped with working skills and knowledge of the working environment, have several options for their careers, and have a clear orientation and positive attitude towards vocational training, intensive education, long-term learning; Be confident, creative and helpful to new technologies, especially communica- 
tion and information technologies, understand the influences of technology on society; have knowledge and concerns about the protection and management of the natural environment, have knowledge and skills in supporting the sustainable development of the ecosystem; Have knowledge, skills and positive attitudes necessary to establish and maintain a healthy lifestyle for creative and comfortable leisure time.

Australian experts have identified seven key competencies (KeyCompetences) for program building and development: capability to collect, analyze and organize information; the capability to communicate information ideas; capability to plan and organize activities; capability to work with others and teammates; capability to use mathematical ideas and techniques; capability to solve problems; capability to use technology.

According to Mr. Nguyen Van Cuong (University of Posdam), in Germany, every state has its own teacher training standards. These standards include four areas of competence: teaching, education, evaluation, innovation and development. Before the year 2000, German teachers were trained in teacher training colleges, but since 2000, teachers have been trained in multi-disciplinary universities and followed European standards. Germany applies parallel training model for general teachers; continuous training model for teachers of vocational schools and vocational education. In terms of the curriculum, the framework program is prepared by the state, based on which the schools themselves develop curriculum. The German general teacher education program is clear and specific to both levels: bachelors and masters, in 6-8 semesters and 2-4 semesters respectively. In Germany, the probationary teacher is the second stage of teacher training after the training in colleges.

In the UK, there are five types of teachers: probationary teacher, teachers, primary teachers, excellent teachers, and advanced teachers. There are teacher qualifications for all of five aboved categories with a standard framework of three areas: professional characteristics, knowledge and specialized skills. The standards of teaching are developed and implemented by the Educational Standard Department. Training and development organizations coordinate with the Education Department to ensure the quality of training, education reform, training courses and the provision of training services, etc. In the UK there are 73 universities offering training programs with a number of supportive programs for teachers to improve the vocational capability and pedagogical skills. There are many ways to become a teacher in the UK: Parallel model (Specialized bachelor + bachelor of education); continuous model (specialized bachelor + 1-2 pedagogical experience years); training model associated with recruitment needs; Training for pedagogical trainees is prepared and conducted by well-qualified teachers, with active teaching methods, giving priority to professional pedagogy practice, carefull observa- 
tion and experience withdraw after theoretical and practical lessons. In the UK, a variety of student-centered learning methods are used. Flexible training program to meet the demands of maximum of learners, the learning time depending on the content of study, the program of training is under the flexible credit system, etc.

The educational model of general teachers in Japan's universities is a parallel 4-year one including: general education, specialization, pedagogica practice, graduation practice and teacher certification program. There are many programs for granting certificates to vocational teachers, focusing mainly on educational methods, professional practice, professional teaching, etc.

The development of training programs needs to be carried out regularly and continuously to create new programs that are up to date and meet the increasing demands of the society.

2.2. The procedures of traing program development physics pedagogy in direction to develop the learner's capability in Vinh University, VietNam

By studying the development of training programs in other countries in the world as well as in Vietnam, we have developed the curriculum for Bachelor of Pedagogy in Physics at Vinh University, Vietnam based on capability approach which follow the following procedures:
Step 1: Conduct surveys and evaluate current and future social practices, identify the orientation, development strategies for current and upcoming general curricula;

Developing a curriculum based on the learner capability approach calls for the process of investigating, analyzing and processing information from a variety of sources, in which we have to identify the social needs and the basic requirements of the program - new textbooks: student capability building, integrated programs, more activities, etc.; In addition, it is necessary to analyze the current status of the current curriculum in terms of advantages, limitations and causes. It is also important to emphasize the actual requirements of employers on the basis of anticipation of new changes and requirements

Step 2: Describe the students' portraits after graduating from the program (qualities, capacities, etc. of students after graduation)

This step is also named as building capability profiles of students after graduation of corresponding training programs. In order to implement this step, it is necessary to work on the system of teachers' qualities defined in the Party's resolutions, the Education Law, the regulations on professional standards of teachers, etc.; Study the international experience, the tradition of education; Factors to help alumni be successfull. To describe learner competencies, it is recommended to use descriptive words which can be observed. 
Step 3: Determine the output standards of the teacher training program

This step means to determine the aim of the education - training process to form, develop personality, general capability and specialized capability of learners. Based on the student's performance record after graduation, the overall goal of the discipline should be determined as the learning outcomes of the program. An output standard set requires a 4-level structure:

Level 1: Areas to be evaluated (or implemented). In the teacher training program, these areas are named as: knowledge, hard skills, soft skills, attitudes and performance capabilities.

Level 2: Criteria (specific contents of a field to be evaluated / implemented)

Level 3: Indicator (only qualitative or quantitative indications to be implemented)

Level 4: Evidence of getting that indicator.

Output standards of each field are different. Standardized output will be the difference points that the school build for the brand of each field and of the school thanks to the working capability of students. It is not only the objective but also the motivation for schools to improve their training activities to meet the needs of the labor market.

Step 4: Study the current teacher training program and develop a new curriculum

Training program design includes frame program design (based on pro- gram output standards); training plans, requirements and conditions to ensure the implementation of the program; the detailed syllabus of each subject (modularized to each credit). In this step, it is neccessary to review the current program, and answering following questions for each subject: what kind of capability does this subject provide to students? (clearly indicating the content of the chapter, the item and comparing with the program's output standards). All subject syllabuses should be reviewed for selection or restructuring of content from multiple syllabus of other subjects so that a new module is integrated into the output standard. The new program is based on the learner-capability approach, therefore, the program must be designed in an integrated way. Only integrated education programs can shape learners' capability (general education, problem solving ability, etc.)

Step 5: Execute the training program: conducting the training program pilot.

Step 6: Evaluate the training program. Evaluation of the training program should be processed with the extensive consultation of scientists, educational specialists, teachers, students and employers, etc.

\section{Conclusion}

Training programs play a very important role in quality assurance of the output. Developing a training curriculum based on learner competency is extremely essential. In order to have a quality training program, it is necessary to start from a capability approach combined with the needs of the em- 
ployers and the society. The development of the curriculum must be a serious job for all universities with more interests and investment. Training programs in general and teacher training programs in particular need to be regularly updated to meet the increasing demands of the society. When developing training programs in general, and those for bachelor of pedagogy in physics in particular, we should concentrate on its high flexibility. This flexibility manifests itself in the program manager as well as the teachers who have rights to proactively propose program adjustments to a certain extent to suit the particular situation in which the goal is to be achieved. In addition, flexibility is also understood as providing opportunities for learners to select courses that match their careers, capability and interests.

\section{Bibliography}

1. Resolution of the 8th Conference of the Central Committee, Session XI (Resolution No. 29 - NQ/TW)
2. Ministry of Education and Training, (2009), Regulations on vocational training standards for Secondary school teachers, Upper secondary school teachers (issued in accordance with Circular No. 30/2009 /TT-BGD \& DT dated on 22/10/2009

3. Edward F. Crawley, Johan Malmqvist, So" ren O" stlund, Doris R. Brodeur, (2009), Re- thinking Engineering Education, The CDIO Approach, Vietnames translating vesion of Ho Tan Nhat and Doan Thi Minh Trinh, Published by National University of Ho Chi Minh city.

4. Doan Thi Minh Trinh (editor), Nguyen Quoc Chinh, Nguyen Huu Loc, Pham Cong Bang, Peter J. Gray, Ho Tan Nhut, (2012), Design and development of training curriculum for standardlized output . Published by National University of Ho Chi Minh city.

5. Sale, D. (2014), The Challenge of Reframing Engineering Education, Singapore: Springer Science+Business Media Singapore

(c) Nguyen Thi N., 2017. 